\title{
Range or meadow regrowth and weaning effects on 2-year- old cows
}

\author{
JAMES B. LAMB, DON C. ADAMS, TERRY J. KLOPFENSTEIN, WALTER W. STROUP, AND GREG P. LARDY
}

\begin{abstract}
Lamb and Adams are research associate and professor, Univ. of Nebraska-Lincoln, Institute of Agr. and Natur. Resources, West Central Res. and Extenstion Center, Route 4, Box 46A, North Platte, Neb. 69101; Klopfenstein and Lardy are professor and research associate, Dept. of Animal Science Univ. of NebraskaLincoln, Lincoln, Neb. 68583; Stroup is professor Dept. of Biometry Univ. of Nebraska-Lincoln, Lincoln, Neb. 68583.
\end{abstract}

Abstract

Eighty 2-year-old spring calving primiparous cows were assigned to 2 weaning and 2 grazing treatments $(20$ cows/treatment) from 7 September to 7 November in 1991, 1992, and 1993. Grazing treatments were native sandhills range or subirrigated meadow regrowth. Weaning treatments were weaning on 7 September or 7 November. Calves weaned on 7 September grazed subirrigated meadow regrowth after weaning. Crude protein of diets from esophagelly fistulated cows averaged $7.6 \%$ on range and $12.3 \%$ on subirrigated meadow on an organic matter (OM) basis. In vitro organic matter digestibility was $55.1 \%$ on range and $61.1 \%$ on subirrigated meadow. No year $X$ grazing treatment or weaning $X$ grazing treatment interactions were detected $(P>0.10)$ for any traits measured. Forage organic matter consumed by cows differed between years: $7.7 \mathrm{~kg} \mathrm{day}^{-1}$ in 1991 and $10.5 \mathrm{~kg} \mathrm{day}^{-1}$ in 1992; but was similar $(P>0.10)$ for all grazing and weaning treatments. Cows grazing meadow gained more body weight and body condition than cows grazing range. Dry cows gained more weight and body condition $(P<0.01)$ than lactating cows. Lactating cows grazing meadow maintained body weight and body condition, while lactating cows grazing range lost body weight and body condition. Calves nursing cows on meadow gained $28.8 \mathrm{~kg}$ more $(P<0.01)$ than calves nursing cows on range and $34.4 \mathrm{~kg}$ more than weaned calves grazing meadow. Body weight gains of weaned calves grazing meadow and calves nursing cows on range were similar $(P>0.10)$. We concluded that dry cows and cows that grazed subirrigated meadow regrowth during September and October increased body condition score over lactating cows and cows grazing range, respectively. Calf body weight gains were greatest for nursing calves on subirrigated meadow, but grazing weaned calves on subirrigated meadow was an effective alternative for calf growth to calves nursing cows on range.

Key Words: subirrigated meadow, intake, digestibility, body condition, beef cattle

Body condition of cows at calving affects pregnancy rate and breeding date (Richards et al. 1986). Body condition score of spring calving cows wintered on range is influenced by fall body condition (Adams et al. 1987). Adams et al. (1993) found that cows suckling calves on Montana range lost body condition dur-

Published with the approval of the director of the University of NebraskaI incoln Agr. Res. Div. as Journal Ser. no. 11254.

Manuscript accepted 24 Feb. 1996.
Resúmen

Ochenta y dos vacas primerizas de dos años de edad fueron utilizadas en dos tratamientos de destete y dos tratamientos de pastoreo (20 vacas/tratamiento), del 7 de Septiembre al 7 de Noviembre durante tres años (1991, 1992 y 1993). Los tratamientos de pastoreo fueron: a) Pastizal nativo y b) Humedales subirrigados. Por su parte los tratamientos de destete fueron: 1) Destete en Septiembre y 2) Destete en Noviembre. Muestras esofágious de la dieta (con vacas fistuladas), promediaron $\mathbf{7 . 6 \%}$ de proteina cruda en el tratamiento a) y $\mathbf{1 2 . 3 \%}$ en el tratamiento b). Los valores de digestibilidad in vitro de la dieta, fueron $55.1 \%$ y $61.1 \%$, para los tratamientos a) y b), respectivamente. No se detectaron interacciones entre tratamientos. El consumo diario de materia organica difirió entre años: $7.7 \mathrm{~kg} / \mathrm{d}$ en 1991 y $10.5 \mathrm{~kg} / \mathrm{d}$ en 1992, más fue similar $(P>0.10)$ en todos los tratamientos. Las vacas en los humedales ganaron significativamente $(P<0.01)$ más peso $(28.8 \mathrm{~kg})$ mientras que las vacas en pastizal nativo perdieron peso y condicción. No hubo diferencias $(P>0.10)$ en los pesos al destete de los tratamientos de pastoreo, más los becerros del destete de Noviembre fueron $34.4 \mathrm{~kg}$. Más pesados que los destetados en Septiembre.

ing August and September. They attributed the loss in body condition to inadequate consumption of crude protein. On a dry basis, diets of cattle grazing Sandhills range during August to October contain 6 to $8 \%$ crude protein (Rittenhouse et al. 1970). Hollingsworth et al. (1995) reported $11.2 \%$ crude protein on an OM basis in diets of cows grazing grass regrowth on subirrigated meadow during October. Meadow regrowth would be a higher quality forage for cattle than range in the fall.

Cow body condition during the fall can be maintained or increased by weaning the calf earlier or providing the cows with supplements (Short et al. 1994). Reducing the cows' nutrient requirements by weaning their calves or by providing them with higher quality forage to meet the nutrient demands might allow the cow to enter winter grazing in higher body condition. Our objectives were to determine if September weaning or grazing subirrigated meadows would improve body condition score of spring-calving primiparous beef cows during September and October over lactating cows on native range and to determine nutrient intakes by dry and lactating cows grazing native range or subirrigated meadow regrowth. 


\section{Materials and Methods}

The study was conducted on native range and subirrigated meadow at the University of Nebraska-Lincoln Gudmundsen Sandhills Laboratory near Whitman, Neb. Eighty 2-year-old crossbred (1/4 Hereford, 1/4 Angus, 1/4 Simmental, and 1/4 Gelbvieh) primiparous beef cows and their calves were assigned to 2 weaning and 2 grazing treatments from 7 September to 7 November in 1991, 1992, and 1993. Grazing treatments were native sandhills range or subirrigated meadow regrowth after July haying. Weaning treatments were weaning on 7 September or on 7 November. Calves weaned on 7 September grazed subirrigated meadow regrowth after weaning in 1992 and 1993.

The range site ( $82 \mathrm{ha}$ ) was classified as sands and was in excellent condition. The dominant grass species were: little bluestem [Andropogon scoparius (Michx.) Nash], prairie sandreed [Calamovilfa longifolia (Hook.) Scribn.], sand bluestem (Andropogon hallii Hack.), switchgrass (Panicum virgatum L.), sand lovegrass [Eragrostis trichodes (Nutt.) Wood], and blue grama [Bouteloua gracilis (H.B.K.) Lag. ex Griffiths]. Common forbs and shrubs include western ragweed (Ambrosia psilostachya Dc.) and leadplant [Amorpha canescens (Nutt.) Pursh].

The subirrigated meadow soils were classified as Gannett-Loup fine sandy loam (course-loamy mixed mesic Typic Haplaquoll). Dominant vegetation on the 45 ha subirrigated meadows site was smooth bromegrass (Bromus inermis Leyss.), redtop (Agrostis stolonifera $\mathrm{L}$.), timothy (Phleum pratense $\mathrm{L}$.), slender wheatgrass [Elymus trachycaulum (Link) Gould ex shinn.], quackgrass [Elytrigia repens (L.) Nevski.], Kentucky bluegrass (Poa pratensis L.), prairie cordgrass (Spartina pectinata Link), and several species of sedges (Carex spp.), and rushes (Juncus spp.). Less abundant grass species were big bluestem (Andropogon gerardii Vitman), indiangrass (Sorghastrum nutans), and switchgrass. Forbs were a minor vegetation component.

Individual cows and calves were weighed and cows scored for body condition after 16 hours without feed or water on 7 September and 7 November. Body condition scores were based on a palpated determination of fleshing over the ribs and thoracic vertebrae. Body condition was scored from 1 (thinnest) to 9 (fattest) according to the system described by Richards et al. (1986).

Fecal output by 40 cows $(10$ cows/treatment) was determined on 7 through 12 October 1991 and 14 through 19 October 1992. Each cow on the intake trial was orally dosed with an intraruminal continuous chromium-releasing device ${ }^{1} 5$ days before a 5 -day fecal collection period. Three to five hundred $g$ of feces were obtained from the rectum of each cow daily at about 0800 .

Twelve esophageally-fistulated cows (6 cows/grazing treatment, avg. body weight $=500 \mathrm{~kg}$ ) were used to obtain diet samples from range and meadow during 1991 and 1992. Diets were collected 9 October 1991 and 15 October 1992. Cows were fitted with screen-bottom collection bags and forage samples were collected during a 30 - to 45 -min. grazing period.

Eight steers in 1991 and 7 steers in 1992 (avg. body weight = $400 \mathrm{~kg}$ ) were assigned to each of the range and meadow grazing treatments. Steers were fitted with fecal collection bags for total

\footnotetext{
${ }^{1}$ Captec Chrome manufactured by Captec Pty. Ltd., Australia, distributed internationally by Nufarm Limited, Manu Street, P.O. Box 22-407, Otahunu, Auckland 6, New Zealand.
}

collection and dosed with the same intraruminal continuous $\mathrm{Cr}$ releasing device as the cows to obtain a correction factor for fecal output (Adams et al. 1991, Hollingsworth et al. 1995). Feces contained in collection bags were weighed, mixed subsampled (150 to $300 \mathrm{~g}$ ), and emptied twice daily at 0800 hours and again at 1800 , during the 5-day collection period.

All fecal and extrusa samples were stored frozen until chemical analyses were performed. Extrusa and fecal samples were freedried and ground to pass a 1-mm screen in a Wiley mill. Dry matter, organic matter $(\mathrm{OM})$, and crude protein (CP) of extrusa and feces were determined by standard methods (AOAC 1990), neutral-detergent-fiber (NDF) was determined according to Van Soest et al. (1991), and acid-detergent-fiber (ADF) by the method of Van Soest (1963). In vitro organic matter digestibility (IVOMD) of esophageal extrusa was determined by the modified procedures of Tilley and Terry (1963) with the addition of $1 \mathrm{~g}$ urea to the inoculum/buffer mixture (Weiss 1994). Fecal samples were analyzed for chromium concentration by atomic absorption spectrophotometry using an air plus acetylene flame (Williams et al. 1962). Forage organic matter intake was calculated by dividing fecal organic matter by the organic matter indigestibility of esophageal extrusa.

Year and year $\times$ pasture were considered random effects. Data were analyzed using mixed model methods of SAS (1990). Because no year $X$ pasture interactions were detected $(P>0.10)$, data were pooled across years. Treatments were arranged as the main plot and weaning treatments as the sub-plot. Treatments were separated using non-orthogonal contrasts. Contrasts were: 1) range vs subirrigated meadow, 2) September vs November weaning, 3) September vs November weaning on subirrigated meadow, and 4) September vs November weaning on range. All differences mentioned in this paper are significant at the $\mathrm{P}<0.01$ probability level unless otherwise noted.

\section{Results and Discussion}

During 1991 and 1992, CP concentration and IVOMD were higher, and ADF and NDF concentrations were lower in fistula forage samples from subirrigated meadow than from range (Table 1). Forage organic matter intake (Table 2) was similar $(P>0.10)$ for all grazing and weaning treatments; pasture $X$ weaning and pasture $X$ year interactions were not significant $(P>0.10)$.

Cow body weights and body condition scores differed $(\mathrm{P}<0.05)$ between range and meadow and between September and

Table 1. Crude protein (CP), neutral-detergent-fiber (NDF), and aciddetergent-fiber (ADF) concentrations and in vitro organic matter digestibility (IVOMD) of diets collected from esophageally-fistulated cows grazing on native range or subirrigated meadow.

\begin{tabular}{lrcc}
\hline \hline & \multicolumn{3}{c}{ Treatments } \\
\cline { 2 - 4 } Item & Range & Meadow & $\mathrm{SE}^{3}$ \\
\hline CP, \% of OM & \\
ADF, \% of OM & $7.6^{* *}$ & 12.3 & 0.6 \\
NDF, \% of OM & $47.8^{* *}$ & 42.9 & 0.8 \\
IVOMD, \% of OM & $79.6^{* *}$ & 64.9 & 1.0 \\
\hline
\end{tabular}

The year $\times$ forage type interaction was not significant $\mathrm{P}>0.10$ for all nutrient items. ${ }^{2} \mathrm{OM}=$ Organic matter.

${ }^{3} \mathrm{SE}=$ Standard error of mean.

**Range and meadow were different $P<0.01$ 
Table 2. Organic matter (OM) intake, body weight, body weight gain, body condition score, and body condition score gain of dry (D) and lactating (L) cows grazing range $(R)$ or subirrigated meadow $(M)$ regrowth from September to November.

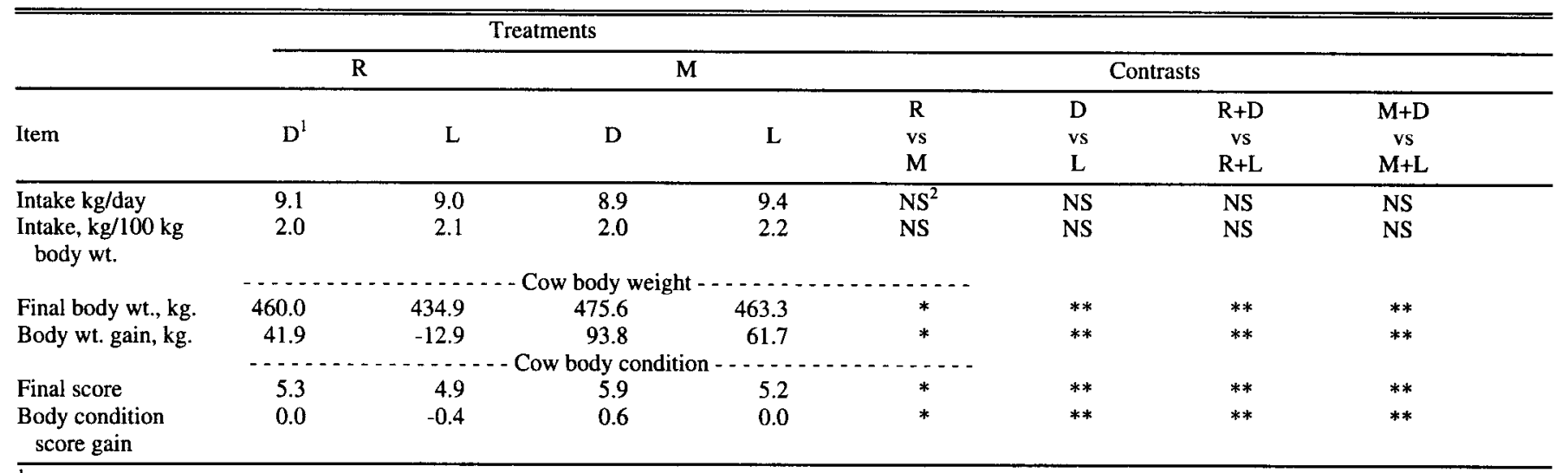

${ }_{1}^{1}$ calves weaned 7 September; $L$, calves weaned 7 November.

${ }^{2}$ NS, Contrast was not significant $P>0.10$.

*, Contrast was significant $P<0.05$.

**, Contrast was significant $\mathrm{P}<0.01$.

November weaning (Table 2). Cows grazing subirrigated meadow regrowth gained more body weight and were heavier at the end of the trial than cows grazing on range $(\mathrm{P}<0.05)$. Dry cows gained more body weight and were heavier at the end of the trial than lactating cows. Year $\times$ grazing treatment and grazing treatment $X$ weaning treatment interactions were not significant.

Lactating cows grazing range had lower body weights and condition scores than dry cows grazing range. Dry cows grazing subirrigated meadow gained more body condition scores and body weight $(\mathrm{P}<0.05)$ than lactating cows grazing subirrigated meadow. Loss of body weight and body condition scores of lactating cows on range have been reported during the late summerearly fall (Adams et al. 1989, Adams et al. 1993).

Importance of weaning and/or forage effects on a production system would be affected by amount of milk produced, growth as with 2-year old cows, late summer body condition score, and available feed resources for the winter. Cows with higher levels of milk production have greater nutrient requirements (NRC 1984) and are more likely to lose body weight and body condition during the late summer-early fall (Adams et al. 1993). If cows are thin in late summer, weaning in September or grazing subirrigated meadow would likely be beneficial. On ranches where cows graze low quality range or consume low quality forage during winter, benefits of weaning and/or grazing meadow could be important. Thin cows grazing range during winter will likely be thin at spring calving (Adams et al. 1987). During winter thinner cows have a greater energy requirement than fatter cows (Thompson et al. 1983) which could make it more difficult for thinner cows to consume enough forage to meet energy require-

Table 3. Body weight and body weight gains of nursing calves grazing range or subirrigated meadow and weaned calves grazing subirrigated meadow from September to November.

\begin{tabular}{lccc}
\hline \hline Item & \multicolumn{2}{c}{ Nursing } & Weaned \\
\hline & Range & Meadow & Meadow \\
Finals body wt., kg. & $232.4^{\mathrm{b}}$ & $264.9^{\mathrm{a}}$ & $230.6^{\mathrm{b}}$ \\
Body wt. gain, kg. & $29.7^{\mathrm{b}}$ & $64.7^{\mathrm{a}}$ & $33.6^{\mathrm{b}}$ \\
\hline
\end{tabular}

IUnweaned, calves weaned on 7 November: weaned, calves weaned on 7 September.

${ }^{\mathrm{ab}}$ Least squares means in same row with different letters differ $\mathrm{P}<0.01$ ments. Increases in cow body condition score duirng winter are not expected (Villalobos 1993) with or without appropriate supplements. Even with supplements, loss of body condition was reported for cows grazing sandhills winter range (Sanson et al. 1990).

Harsh winter weather would also affect the importance of body condition score. During harsh weather cows consume less range forage and digestibility is reduced (Kartchner 1980, Adams et al. 1986). Maintenance requirements of the cow are also increased during cold (NRC 1984), making it difficult for cows to consume enough forage to meet energy requirements.

Body condition score is more closely related to reproduction than is body weight in beef cattle (Dziuk and Bellows 1983). Cows in low body condition (i.e., score $<4$ ) at calving may breed later or fewer will breed during a controlled breeding season than cows in higher body condition (i.e., score $>5$ ), especially if body condition is declining between calving and the beginning of the breeding season (Richards et al. 1986).

Body weight of calves at the beginning of the trial was similar for all treatments each year (data not shown). Body weights of calves on 7 November and body weight gains over the trial of calves nursing cows on subirrigated meadow were greater than calves nursing cows on range or weaned calves grazing on subirrigated meadow (Table 3). Body weight on 7 November of calves weaned in September was similar to that of suckling calves grazing range.

The increased gains of calves nursing cows on meadow regrowth over calves nursing cows on range is partially explained by the difference in chemical composition of diets between range and meadow forage, especially crude protein. The protein content of the forages would have affected the quality of the calf diets and possibly the amount of milk produced by the cow and consumed by the calf. The improved body weight gain of nursing calves on meadow over weaned calves on meadow is best explained by more rumen escape protein provided by the milk to the intestines. Milk protein escapes ruminal digestion via the esophageal groove (Ruckebusch 1988). Hollingsworth-Jenkins (1994) found that, in calves grazing vegetative range, escape protein was limiting before energy or rumen degradable protein. 


\section{Conclusion}

For production systems where cows are wintered on low quality forages, maintenance, or increased body condition during the summer or fall could be a benefit. Gain in body condition score during winter would not be expected.

We concluded that weaning in September or grazing subirrigated meadow regrowth during September and October maintain or increase body condition and body weight over cows suckling a calf or grazing range, respectively. Where there is not enough subirrigated meadow regrowth or a comparable high quality forage to support both cows and calves, weaning and grazing the calf on meadow or comparable forage and grazing a dry cow on range offers potential to maintain calf gains while maintaining or improving body condition of the cow.

\section{Literature Cited}

Adams, D.C., T.C. Nelsen, W.L. Reynolds, and B.W. Knapp. 1986. Winter grazing activity and forage intake of range cows in the Northem Great Plains. J. Anim. Sci. 62:1240-1246.

Adams, D.C., R.E. Short, and B.W. Knapp. 1987. Body size and body condition effects on performance and behavior of grazing beef cows. Nutr. Rep. Int. 35:269-277.

Adams, D.C., R.B. Staigmiller, and B.W. Knapp. 1989. Beef production from native and seeded Northern Great Plains ranges. J. Range Manage. 42:243-247.

Adams, D.C., R.E. Short, M.M. Borman, and M.D. McNeil. 1991. Estimation of fecal output with an intraruminal continuous release marker device. J. Range Manage. 44:204-207.

Adams, D.C., R.B. Staigmiller, B.W. Knapp, and J.B. Lamb. 1993. Native or seeded rangeland for cows with high or low milk production. J. Range Manage. 46:474 478.

AOAC. 1990. Official Methods of Analysis (14th ed.). Association of Official Analytical Chemists. Washington, D.C.

Dziuk, P.J. and R.A. Bellows. 1983. Management of reproduction of beef cattle, sheep, and pigs. J. Anim. Sci. 57 (Supp. 2):355-379.

Hollingsworth, K.J., D.C. Adams, T.J. Klopfenstein, J.B. Lamb, and G. Villalobos. 1995. Supplement and forage effects on fecal output estimates from an intra-ruminal marker device. J. Range Manage. 48:137-140.

Hollingsworth-Jenkins, K.J. 1994. Escape protein, rumen degradahle protein, or energy as the first limiting nutrient of nursing calves grazing native Sandhills range. Ph.D. Thesis, Univ. Nebraska, Lincoln, Ncb.

Kartchner, R.J. 1980. Effects of protein and energy supplementation of cows grazing native winter range forage on intake and digestibility. $\mathbf{J}$. Anim. Sci. 51:432-438.

NRC. 1984. Nutrient requirements of beef cattle (6th ed.). Nat. Acad. Press, Washington, D.C.

Richards, M.W., J.C. Spitzer and M.B. Warner. 1986. Effect of varying level of postpartum nutrition and body condition at calving on reproductive performance in beef cattle. J. Anim. Sci. 62:300-306.

Rittenhouse, L.R., D.C. Clanton, and C.L. Streeter. 1970. Intake and digestibility of winter range forages by cattle with and without supplements. J. Anim. Sci. 31:1215-1221.

Ruckebusch, Y. 1988. Motility of the gastro-intestinal tract, p. 64. In: D.C. Church (ed.). The Ruminant Animal Digestive Physiology and Nutrition. Prentice Hall.

Sanson, D.W., D.C. Clanton, and I.G. Rush. 1990. Intake and digestion of low-quality meadow hay by steers and performance of cows on native range when fed protein supplements containing various levels of corn. J. Anim. Sci. 68:595-603.

SAS. 1990. SAS User's Guide: Statistics. SAS Inst. Inc., Cary, N.C.
Short, R.E., R.B. Staigmiller, R.A. Bellows, D.C. Adams, and J.G. Beradinelli. 1994. Effects of suckling on postpartum reproduction. $p$. 179-187. In: M.J. Fields and R.S. Sand (eds.). Factors Affecting Calf Crop. CRC Press, Inc. Boca Raton, Fla.

Thompson, W.R., J.C. Meiske, R.D. Goodrich, J.R. Rust, and F.M. Byers. 1983. Influence of body composition on energy requirements of beef cows during winter. J. Anim. Sci. 56:1241-1252.

Tilley, J.M.A. and R.A. Terry. 1963. A two-stage technique for the in vitro digestion of forages. J. Brit. Grassl. Soc. 18:104-111.

Van Soest, P.J. 1963. Use of detergents in the analysis of fibrous feeds. II. A rapid method for the determination of fiber and lignin. J. AOAC. 46:829-835.

Van Soest, P.J., J.B. Robertson, and B.A. Lewis. 1991. Methods for dietary fiber, neutral detergent fiber, and non starch polysaccarides in relation to animal nutrition. J. Dairy Sci. 74:3583-3597.

Villalobos, G. 1993. Integration of complementary forage with native range for efficient beef in the Sandhills of Nebraska. Ph.D. Thesis, Univ. Nebraska. Lincoln, Neb.

Williams, C.H., D.J. David, and O. Iismaa. 1962. The determination of chromic oxide in feces samples by atomic absorption spectrophotometry. J. Agr. Sci. (Camb.) 59:381-385.

Weiss, W.P. 1994. Estimation of digestibility of forages by laboratory methods, p. 644-681. In: George L. Fahey, Jr. (ed.), Forage quality, evaluation, and utilization. Amer. Soc. Agron., Inc., Crop Sci. Soc. Amer., Inc., Soil Sci. Soc. Amer., Inc., Madison, Wis.

Statement of Ownership, Management, and Circulation

(Act. of August 12, 1970, Sec. 3685, Title 39, United States Code)

1. Title of Publication: Journal of Range Management

2. Date of Filing: September 27, 1996

3. Frequency of Issue: Bimonthly

4. Location of Office of Publication: 1839 York Street. Denver. Colo. 80206

5. Location of General Business Office: Same

6. Name and Address of:

Publisher: Society for Range Management, 1839 York Street, Denver, Colo. 80206

Editor: Gary Frasier, 7820 Stag Hollow Rd., Loveland, Colo. 80538 Managing Editor: Dr. Charles Rumburg, 1839 York Street, Denver, Colo. 80206

7. Owner: Society for Range Management, 1839 York Street, Denver, Colo. 80206

8. Known Bondholders, Mortgages, etc.: Membership

9. For Completion by Nonprofit Organizations Authorized to Mail at Special Rates: The purpose, function, and nonprofit status of this organization and the exempt status for Federal income tax purposes have not changed during preceding 12 months.

10. Extent and Nature of Circulation

A. Total copies printed

B. Paid Circulation

1. Dealers, counter sales

2. Mail subscriptions

C. Total paid circulation

D. Free distribution

E. Total distribution

F. Copies not distributed

G. Total

$\begin{array}{cc}\begin{array}{c}\text { Avg. for } \\ 12 \text { months }\end{array} & \begin{array}{c}\text { Actual for } \\ \text { issue nearest } \\ \text { filing date }\end{array} \\ 4,945 & 4,843 \\ 0 & \\ 4,418 & 0 \\ 4,418 & 4,304 \\ 16 & 4,304 \\ 4,434 & 16 \\ 511 & 4,320 \\ 4,945 & 523 \\ & 4,843\end{array}$

I certify that the statements made by me above are correct and complete -Charles B. Rumburg, Managing Editor. 